\title{
The uneven struggle for bluefields: waterfront transformation in post-socialist Bratislava
}

\author{
BRANisLAV MACHALA ${ }^{1}$
}

\begin{abstract}
Waterfront areas are undergoing rapid transformation in many post-socialist cities. This paper focuses on the uneven access to the waterfront in post-socialist Bratislava. We use the bluefield concept of PINCH, P. and Munt, I. (2002). The goal of the paper is to investigate the mechanisms and key forces of waterfront transformation in post-socialist Bratislava in the context of institutional practices, where the role of individual stakeholders and planning are critically evaluated. The limited capacity of post-socialist institutions to mediate and respond to the dynamically increasing demand to waterfronts is highlighted. In the paper two case study areas are investigated with sharply different conditions. In the case of Karlova Ves cove contradictions between the use value and exchange value is demonstrated, leading to a sharp struggle among potential users. The transformation of the second chosen area, Jarovce river branch, demonstrates a power invasion in the area and the illegal privatisation of public areas by 'better off' people. The comparison of transformations of these two localities in a relatively similar time frame, provides a picture about the uneven struggle for access. Both discussed examples draw attention to persisting institutional adaptation and the fragile de facto position of the municipality in urban development.
\end{abstract}

Keywords: waterfront transformation; bluefield regeneration; uneven development; postsocialist city; urban planning; Bratislava;

\section{Introduction}

Delayed industrial decentralization in post-socialist cities combined with their dynamic adaptation to new socio-economic and political conditions is significantly reflected at urban waterfronts. Nowadays, urban areas in the vicinity of boatyards previously symbolic for industrial development are adopting to new socio-economic needs. Meantime post-socialist cities open to new flows of capital, the globalisation of real estate market, along with other significant factors are gradually changing

\footnotetext{
${ }^{1}$ Department of Social Geography and Regional Development, Faculty of Science, Charles University Prague, Albertov 6, 128 43, Praha 2, Czech Republic. E-mail: branislav.machala@gmail.com
} 
their socio-spatial structure. Under these circumstances waterfronts represent areas of conflicts, where different interests of various stakeholders and hierarchy levels are clashing in the fragile post-socialist institutional environment.

The post-socialist cities of Central and Eastern Europe (e.g. Belgrade, Bratislava, Budapest, Prague, Tallinn) are good examples for pervasive waterfront transformations. However, it is also necessary to underline that these cities have different trajectories and starting positions. The literature to date dedicated to industrial decentralization in post-socialist cities focuses either on the structural-horizontal changes in these cities (e.g. KIss, É. 2007; SÝKORA, L. 2001, 2007; Temelová, J. 2009), or the transformation of selected urban districts (e.g. BUČEK, J. 2006; ILÍK, J. and Oǔ̌EDNíČEK, O. 2007). Other authors focus on the asymmetric relations between the main stakeholders of urban development and the practices of urban development and planning (e.g. Сook, A. 2010; Nedović-Budić, Z. 2001; Stanilov, K. 2007). Only limited attention has been paid so far to the radical transformation of urban waterfronts, their causes and conditions; or their wider socio-economic and political implications.

This paper aims at evaluating the role of individual stakeholders in the transformation of selected bluefield areas in post-socialist Bratislava, with special attention to the role of public institutions and urban planning. We focus on the ongoing waterfront transformation in Bratislava on the micro-level, with two separate and highly contrasting case studies. Both cases belong to that part of the waterfront which is functionally closely related to the water surface (e.g. harbours, shipyards, bays for water sports, houseboats etc.). The reason why we pay specific attention to these localities is their dependence on water as a public good as well as their social background. PINCH, P. and MunT, I. (2002) consider the infrastructure dependent on water as "bluefield“. We understand by this also the adjacent area with primary functions basically dependent on water.

Our paper is divided into three parts. In the first section we put the transformation of bluefield areas into a wider theoretical context. We provide an overview about the literature on waterfront development and also present key concepts that help identifying areas and defining the main driving forces leading to their transformation.

The second section of the paper focuses on the transformation of Karlova Ves cove, where the progress shows a struggle between water enthusiasts and citizens for preservation and development of activities dependant on water. Based on our research we identify three main areas that significantly influence the current image of transformation of the area. The third part offers a contrasting case of transformation, the river branch in Jarovce where we observe the occupation of the area by a closed group of politically, economically and socially powerful people whose status is in sharp contrast with water enthusiasts of Karlova Ves cove. In the conclusion we summarise our findings from the two cases and discuss their wider implications. 


\section{Conceptualising waterfront transformation}

Waterfront transformation has been discussed in scientific literature for more than half a century. The first studies focused on mutual relationships between city and harbour and visualised them with general models. Later, several publications contributed to the conceptualisation of waterfront transformation (e.g. Hoyle, B. et al. 1988; Bruttomesso, R. 1993; Malone, P. 1997; Marshall, R. 2001; Desfor, G. et al. 2011).

Waterfronts have been and often are used in favour of pro-growth strategies in the growing international competition of cities. Many urban geographers and authors from other disciplines focused on waterfronts as spatial laboratories. They analysed waterfronts from various perspectives such as the symbolic value of waterfronts regarding the planning or the marketing of the city (SHORT, J.R. et al. 1993). The conflicting nature of waterfront regeneration and the role of various stakeholders were evaluated in the case of Berlin by Scharenberg, A. and Bader, I. (2009). Perceptions of citizens and the socio-economic impact of flagship projects were investigated by Doucet, B. et al. (2010). Significant interest has also been paid to the role of planning documents, applied policies and regimes of governance (e.g. Coincetto, E. 2007; Hoyle, B. 2000; Breen, A. and Rigby, D. 1994; Feldman, M. 2000; Gordon, D.L.A. 1996, 1997; Marshall, R. 2001; Imrie, R. et al. 2009).

However, only a limited number of papers put the emphasis on the conceptualisation of waterfront transformation, its relevance for society, and the complex relationships within urban region at different hierarchical levels. Critical urban geographers looked at the relationship between urbanisation, capital, water and development (e.g. Swynegdouw, E. 2004; Harvey, D. 1989; Malone, P. 1997). Marcuse and Van Kempen, R. (2000) labelled waterfronts as "soft location", i.e. areas where processes of globalisation and post-fordist transformation are even more obvious and have specific socio-spatial implications. Only a few studies of waterfront transformation have shown deeper causality and evaluation of outcomes for the city and its society. In a certain way we lack a critical discussion about the legitimacy of the newly built, functionally mixed projects replacing old functions. Where such studies exist, they question their contribution to society as a whole (Pinder, D.A. and Hoyle, B.S. 1992).

The movement of people, goods and capital is typical for waterfronts and makes them a gate into the city. Desfor, G. et al. (2011) presented a geographical conceptualisation of waterfront transformation with the ,fixity and flows' concept based on underlining static and dynamic elements of the environment. They pointed out the understanding of waterfronts as places existing within the networks of historical relationships, through transportation of objects, information and people. These historical relations significantly influence the origin of power relations in the whole network. Desfor, G. et al. compares the impacts of power 
relations on space with the influence of flows emphasised by CASTELLS, M. (1996), who highlights the importance of informational and technological revolution in the 1980s and its influence on economics. The importance of power relations in the multiple transformations of post-socialist cities are also emphasised by SýKORA, L. and BouZarovsKI, S. (2012). According to them post-socialist cities are cities in transition which experience revolutionary changes as an outcome of their long societal evolution which has path dependent character (SÝ́коRA, L. 2008).

We understand by waterfront transformation a continuous process of urban adaptation from industrial to post-industrial waterfront development triggered by technological innovation and a complex set of socio-economic relations which have been transforming waterfronts into places with a postmodern consumer culture and increasingly segregated places with a dual character.

Waterfronts represent transforming localities where people, capital, institutions and politics play a crucial role. Waterfront transformation has usually an overall impact on the city and its region (e.g. the Bilbao effect). Waterfronts have been frequently used in place-making and competition for global capital at the expense of social justice and direct social displacement. At the same time we think that during the evaluation of this transformation the geography of places, different social needs, urban hierarchy and institutional environment of different cities cannot be ignored. Therefore, we think that time, space and scale should be fundamental criteria in various attempts to evaluate such transformations.

In this paper we focus on specific parts of waterfronts which we consider especially important when we talk about transforming waterfronts, namely 'bluefields'. PINCH, P. and Munt, I. (2002, p. 172) define 'bluefield' as "Infrastructures, such as piers, wharfs, jetties, slipways and boatyards, need to be acknowledged as inextricably related to the use and 'development' of waterspaces" and could be reclassified as 'bluefield' sites". However, we widen its application for infrastructure as well as adjacent shores i.e. areas with functions that are primarilly dependent on water surface and creates a background for water related activities. Or to put it in other words, areas and infrastructure that mediate interactions between water and land. We use the "bluefield“ concept to draw the attention to the heterogeneity of shores which are currently represented in urban planning from a land based perspective and by terrestrial discourse. This heterogeneity has an influence on people's physical access to water and its uneven transformation has therefore social consequences for whom and where these gates are open. This article shows an uneven struggle for these sites in two case studies: Karlova Ves cove and Jarovce river branch.

The growing capital value of the waterfront in post-socialist Bratislava generates increasing disconformities between the use and exchange value of these sites, considered also by David Harvey (2014) to be one of the basic contradictions of capitalism. Both areas are used for active and passive recreation in an increasingly dense urban core of Bratislava. Therefore, these functions 
especially in Karloveska Cove have high use value for citizens. On the other hand, increasing capital value of the land increases the pressure and, therefore, the exchange value of this land on the real estate market. As a consequence, new functions with higher exchange value replace water related activities. These disconformities between the use and exchange value have a wider social impact when the popular functions historically located in certain areas are being replaced according to the exchange value of the land for a significantly narrower group of consumers. Due to the pressure of exchange value such geographically and socially valuable areas are becoming socially more selective and within the current uneven transformation functionally more homogenous.

\section{Research questions and methodology}

The process of waterfront transformation in post-socialist Bratislava characterised by asymmetric power relations among stakeholders raises several questions: What are the benefits of the transformation for the city and its citizens? Does this transformation increase the quality of life of local people and their happiness? Who influences the outcomes and impacts of the waterfront transformation? What type of injustices are being created and how they could be avoided? Bearing these questions in mind, we focus on cases which provide different access to water for people with different social and power position in the society and we analyse the role of planning and institution in this process. Consequently, we can contribute to the debate on how uneven and dual the transformation really is.

The main research techniques we applied were: qualitative analysis of planning and other official documents, content analysis of media coverage, semi-structured in-depth interviews and a field survey. Subsidiary knowledge and information were obtained from a series of public discussions thematically aimed at Bratislava waterfront (2011), from the professional seminar "turn towards the river"2 and, "urban-walk"3 in Karlova Ves cove.

We evaluated the following spatial planning documents: Land Use Plan of the Slovak capital Bratislava (2007), Changes and amendment to land use plan 02 (2010), Urbanistic zone study Karlova Ves cove (2003) and Law from the $27^{\text {th }}$ of April 1976 on spatial planning and construction order. In the above mentioned spatial planning documents we focused on the obligatory but in some cases also on non-obligatory parts and their perception and importance for examined areas of the city.

\footnotetext{
${ }^{2}$ International seminar organised by the author of this article in 2013, was dedicated to the issue of waterfront regeneration. Participants included actors from the public and private sector, academics etc.

${ }^{3}$ Urban walk - project organised by Tomáš Hanáčik in Karlova Ves cove in 2013
} 
In both cases we first made a chronological reconstruction of the historical genesis of the area mostly based on primary documents (official information documents, petition documents etc. altogether 11 documents), analysed media documents (local newspapers, state-wide journals, web pages and portals etc.) and acquired information from semi-structured discussion. Information was acquired by analysis of daily press, internet and media, verified by triangulation - within the primary sources and actors. The statements of stakeholders published on their own web pages were interpreted.

Semi-structured interviews with main stakeholders included representatives of the city, state institutions; independent professionals; water sportsmen, activists; prosecutor. They were the main sources and verifying tools of the acquired information and attitudes. In several cases we used phone calls, or email and in the case of newcomers informal discussions. In total 14 people were interviewed - some of them twice in order to verify and specify the collected information.

\section{Karlova Ves cove: struggle for access to water}

Karlova Ves cove represents a valuable area with citywide importance from the environmental point of view as well as from its historical role regarding

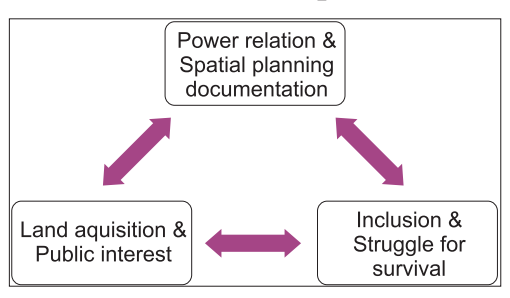

Fig. 1. Mechanism of waterfront development at Karlova Ves cove water sports. Several generations of water sportsmen were trained in the area who represented Slovakia and Czechoslovakia at the most prestigious international sport events. Considering the mechanisms of Karlova Ves cove's transformation, we identified 3 key areas which significantly influence the development of the area (Figure 1).

\section{Portioning Karlova Ves cove: power relations and spatial planning}

Portioning of Karlova Ves cove is a continuous process. As a first step an urbanistic study for the area was elaborated, which was followed by changes in relevant spatial planning documents. These changes showed the growing interest of the market towards the cove in favour of higher exchange value (i.e. residential function). The question arises who is favoured by the rezoning process and to what extent urban development is regulated and controlled by the public sector in Bratislava. Before we start the analysis of the planning process it is necessary to underline that the city's land-use plan (further LUP) itself allows a wide range of interpretations due to the disequilibrium between the obligatory and non-obligatory parts. 
When the transformation of Karlova Ves cove started (around the turn of the new millennium), a LUP from 1993 regulating the use of the area in scale of 1:25,000 was still valid. The urbanistic study of 2003 elaborated by a private company regulated the area in scale of 1:1,000 and became the main spatial planning groundwork for the 'Karloveske rameno I.' project. The project envisaged the dominance of housing function, surrounded by a boatyard and auxiliary buildings from the west and the reconstruction of the former Slavia complex with a dominant function of water sports in the east. The project was completed between 2004 and 2006 and it became one of the first contemporary interventions at Bratislava's waterfront. Two newly built residential objects were constructed at the edge of the regulated area (with codes $501^{4}$ a $401^{5}$ ).

The comparison of the satellite image of the area with the proposals of the urbanistic study shows clearly the development of a poly-functional area (Photo 1 and Figure 2.). This discrepancy between the urbanistic study and reality was caused by the non-obligatory nature of the urbanistic study which has from the legal point of view only recommending character. So while the urbanistic study was created especially for the project, at the end of the day it had no binding influence on the extent of designed project.

In 2007 the new LUP which integrated main elements of the urbanistic study of 2003 was approved. This brought about an extension of 501 code (func-

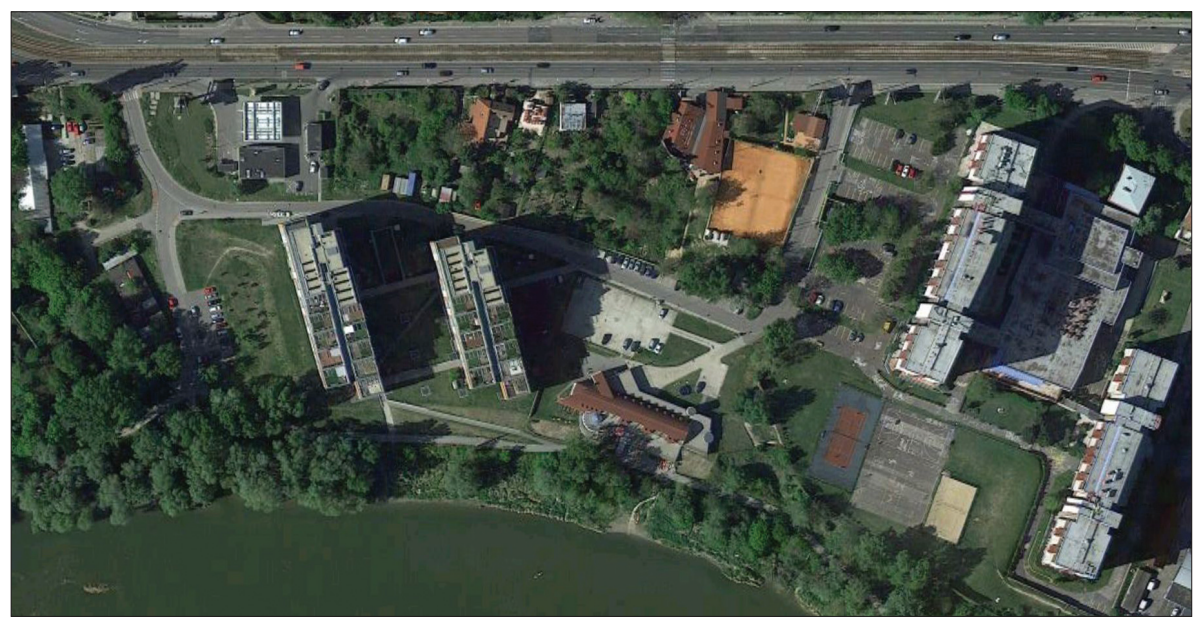

Photo 1. Satellite image of the area. Source: Google Earth

\footnotetext{
${ }^{4} 501$ - mixed territories of housing and civic facilities

${ }^{5} 401$ - sport, physical education and leisure
} 


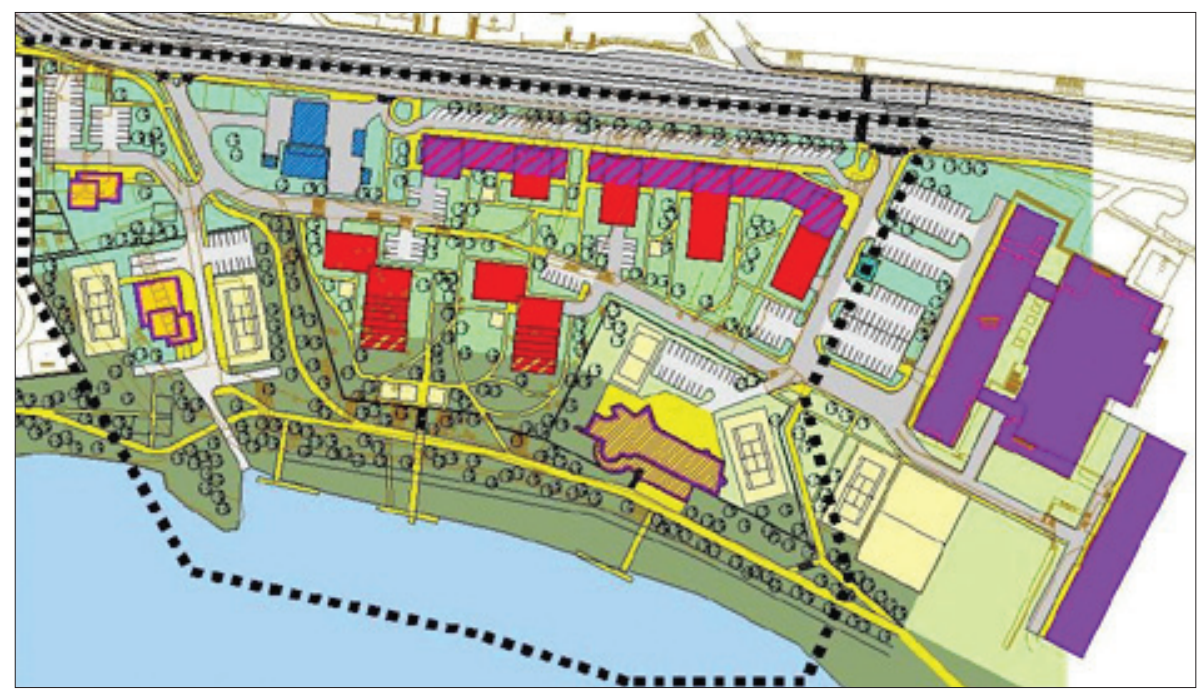

Fig. 2. Complex functional usage proposed by the urbanistic study Source: Urbanistic study, 2003.

tionally mixed areas) at the expense of 401 code (areas designated for sport, physical education and leisure) and changed the scale of regulation from 1:1,000 to $1: 10,000^{6}$. This important change removed from the planning document the detailed resolution of functional and spatial planning in scale 1:1,000, which has been replaced by general regulation of 501 and 401 codes in scale 1:10,000. As later on became clear, the shift in scale of planning documents in combination with extension of code 501, created preconditions for the expansion of mixeduse functions on the land previously dedicated to sport and leisure.

\section{Private-public partnership}

After the completion of the first phase of 'Karloveske rameno I.' the transformation of Karlova Ves cove was supposed to continue with the construction of the identical third building with a similar function but different name, on a neighbouring area (Photo 2). During the period of project preparation there

${ }^{6}$ It has to be mentioned that regulation of the urbanistic study was non-obligatory - obligatory at that time was regulation of the previous LUP 1:25,000. In other words, if we have ignored the urbanistic study, the obligatory scale has changed from 1:25,000 to $1: 10,000$. Regardless the urbanistic study being obligatory or not, it is still an official planning document that was elaborated in cooperation between the municipality and elaborator/investor for the purpose of a more detailed regulation of the concerned area. 


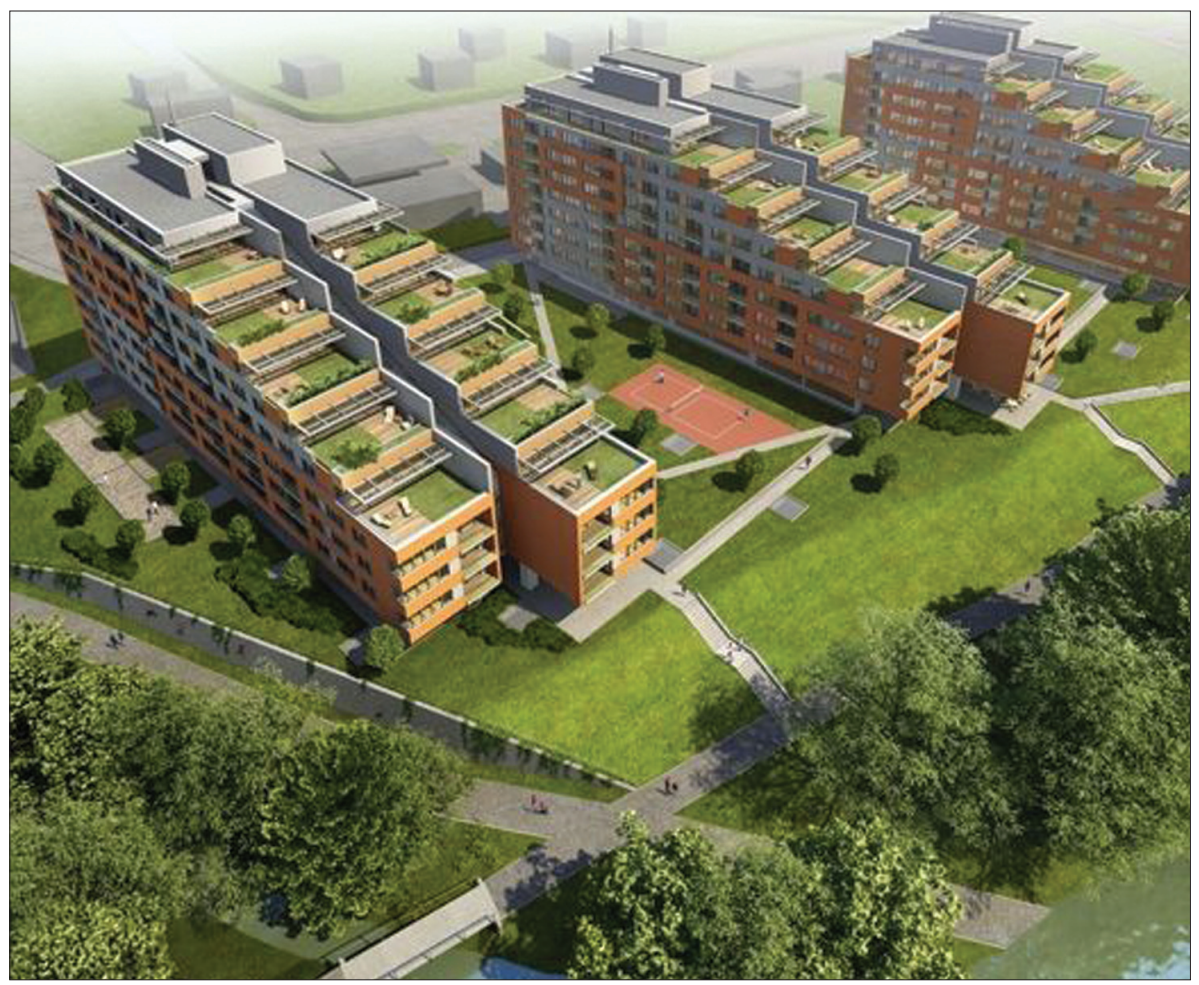

Photo 2. The proposed scheme of 'Karloveske rameno III.' project. Source: www.skyscrapercity.com

was a change in the definition of planning code 401. Although the original one had a less rigorous wording it forbade construction of apartment blocks. However, the acting director of the company stated in a national newspaper that as well as sportsmen from local sport clubs, anyone interested in buying a flat could live in the building.

Surprisingly, the municipality issued a concurrent binding declaration for the object construction even without examining detailed fulfilling of the regulation of the area, for which it was later blamed for by the procurator. The subject matter of the concurrent binding declaration was attacked by the general attorney office (repeatedly called for by the citizens). The municipality after the protest of the general attorney's office did not approve its previous suggestions, but came up with its own explanation why it cannot approve the previous concurrent binding declaration. So at the end the municipality froze the project due to formal reasons which are not in line with the arguments of citizens and attorney. In other words the municipality defended itself and is still in line with the investment. 
The selection process of elaborator of planning document for the area was realised on the basis of public procurement, where the main criterion was the price. The reality as one of the respondents noted is "Competition for competition. In reality it is about who is the most courageous to give a price that would not even cover the basic expenses". The member of the construction and territorial planning committee of city district Karlova Ves stated that the office deals with dumping prices. The winner of the public procurement process estimated his two year work of territorial plan elaboration for 1,500 EUR, the second bid was 4,500 EUR.

The estimation of a qualified respondent was at minimum 4.5-5 times higher than the price of the current elaborator. The process of selection of private elaborator on the basis of price - not idea (or content and quality), strengthened the power of private actors in elaboration of territorial planning and led to the selection of the same elaborator who prepared the case of study in 2003. It was the mayor of Karlova Ves district who chose the elaborator of the regulatory documentation directly on the basis of the second lowest price in the public procurement process.

\section{Land acquisition and public interest}

The interest of developer in Karlova Ves cove was manifested in buying the plots in the area. The lots included in 'Karloveské rameno I.' were expanded on both sides of the project. Almost two months after the approval of the new spatial plan (which expanded the surface of 501 code in the area) the city district Karlova Ves sold the public property directly to a developer company without any competition. The sale was initiated by the mayor of Karlova Ves. The representatives of Karlova Ves and the city approved the sale of the estate on the basis of information regarding function and general intention, without any knowledge about specific functional and spatial segmentation of the estate (moreover, the estate was crossed by the border dividing the area between codes 401 and 501).

After signing the contract of sale, a private-public partnership was set up. It took more than ten months for the developer to fulfil its obligations according to the signed contact while the municipality or the city could cancel the contract after 30 days. During these ten months, on the one hand a civic petition "Save the access to the Danube and Karlova Ves cove for the citizens" was initiated, while on the other hand the city gave permission for the developer (before it settled its obligations) to cut out trees in the area still owned by the city. This clearly shows that the municipality favoured private interests. 
The civic movement became one of the key stakeholders in the transformation of Karlova Ves cove. It was the activity and endeavour of non-organized public that defended its rights to the area in this uneven struggle. Three weeks after the public hearing of the direct sale of the estates in Karlova Ves cove, citizens wrote and signed a petition called "Save the access to Danube and Karlova Ves bay for the citizens". The citizens used this petition to express clearly their fears of the proposed project.

Despite the civic petition, (almost seven months from petition formation) the district mayor and the former mayor of Bratislava signed the contract with the developer company without any selection procedure. After complicated obtaining of the information that the estate was finally sold, the citizens started again a new petition under different name "Safe the access to the waters of Danube in Karlova Ves cove for the citizens." Among the main arguments of the petition were: "...significant limitation of sport activities development in this area, mostly for the youngsters; limiting the access of citizens to the river branch of Danube, to the cycle route and new promenade". The public and water sportsmen clearly declared their feeling that the development is not supporting but limiting the development of sports activities in Karlova Ves cove.

\section{Jarovce river branch: demonstration of power in the urbanisation of water}

Boathouses began to appear in the Jarovce river branch of the Danube in Bratislava after the Velvet Revolution. During communism the Danube as international border-zone was strictly regulated and controlled. After opening the area to the public Jarovce river branch became the target of a small group of wildlife enthusiasts, active fishermen and water sportsmen whose boats and boathouses started to spread there. In 1993 there were only 3 boathouses in the river branch belonging to pri-

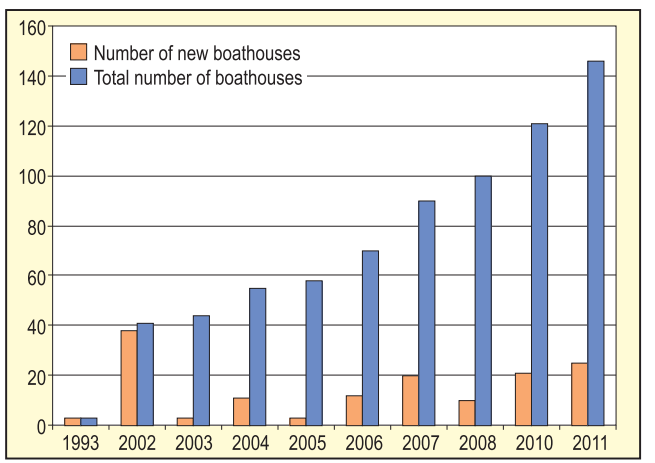
vate owners, however, since 2002 their number has started to grow rapidly and by 2001 it reached 146 (Figure 3). Simultaneously, the interest in mooring in the Jarovce river branch grew enormously.

Fig. 3. Number of boathouses in the Jarovce arm of the Danube. Source: Plus 7 dni 
The current capacity of mooring in the Danube's meander in Jarovce is defined as 226 positions by the Slovak Water Management Enterprise. Out of them about 150 are already occupied. The average price of a boathouse is estimated to be between 100 and 200 thousand EUR.

$$
\text { Rules - just for some }
$$

In terms of land use regulations we can conclude that the territory is regulated in favour of active recreation and preservation of the natural environment. Jarovce river branch is part of the protected forests near the Danube. However, not all of the new boathouses are owned or occupied by enthusiasts of nature, just the opposite.

Damage caused by newcomers in the protected area are estimated by the State Nature Conservation Office to be 437,713 EUR. These damages were caused by cutting out of protected trees, shrubs or other vegetation in order to make easy access to the river. Illegally modified river banks, construction of summer shelters or other permanent structures, building access roads for cars led to a fundamental change in the character of the conservation area. None of these structures built on the river bank met the criteria set by legislation and the city LUP. They were built arbitrarily without planning or acquiring building permission. Moreover, the absence of defining a boathouse in the law as property guarantees the owners' exemption from tax (property tax), at the same time owners enjoy sewage, and water supply free of charge. Therefore, newcomers do not normally ask permit from the Building Authority, but only mooring permission from the Traffic Department (former State Navigation Administration).

The inherited, inflexible but still valid Building Act from 1976 is constantly criticised especially for the easy legalisation of illegal constructions. Demolition of illegal buildings has hardly occurred. The main obstacle to the clearance of illegal constructions is the unknown ownership of the property.

\section{Illegal colonisation of water}

In Jarovce river branch the power ambitions of boathouse owners in the form of privatisation of public spaces can clearly be observed. State-owned river banks in the administration of the Slovak Water Management Enterprise have been gradually annexed to boathouses through the symbolic enclosure of front gardens (Photo 3). Privatization of the public area through barriers and ramps built by boathouse's owners and preventing access to boathouses is also widespread (Photo 4). This process can be described as the colonisation of the Jarovce 


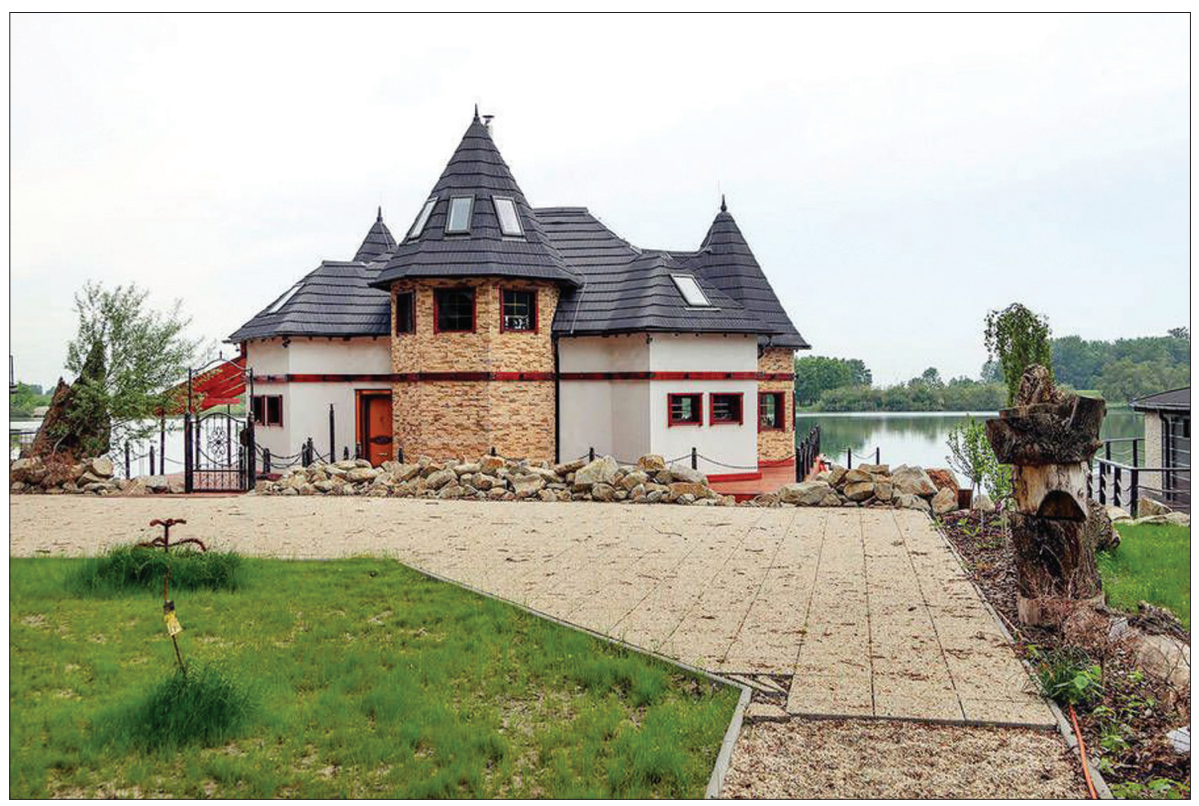

Photo 3. Luxurious boathouse in the Jarovce arm of the Danube. Source: www.cas.sk

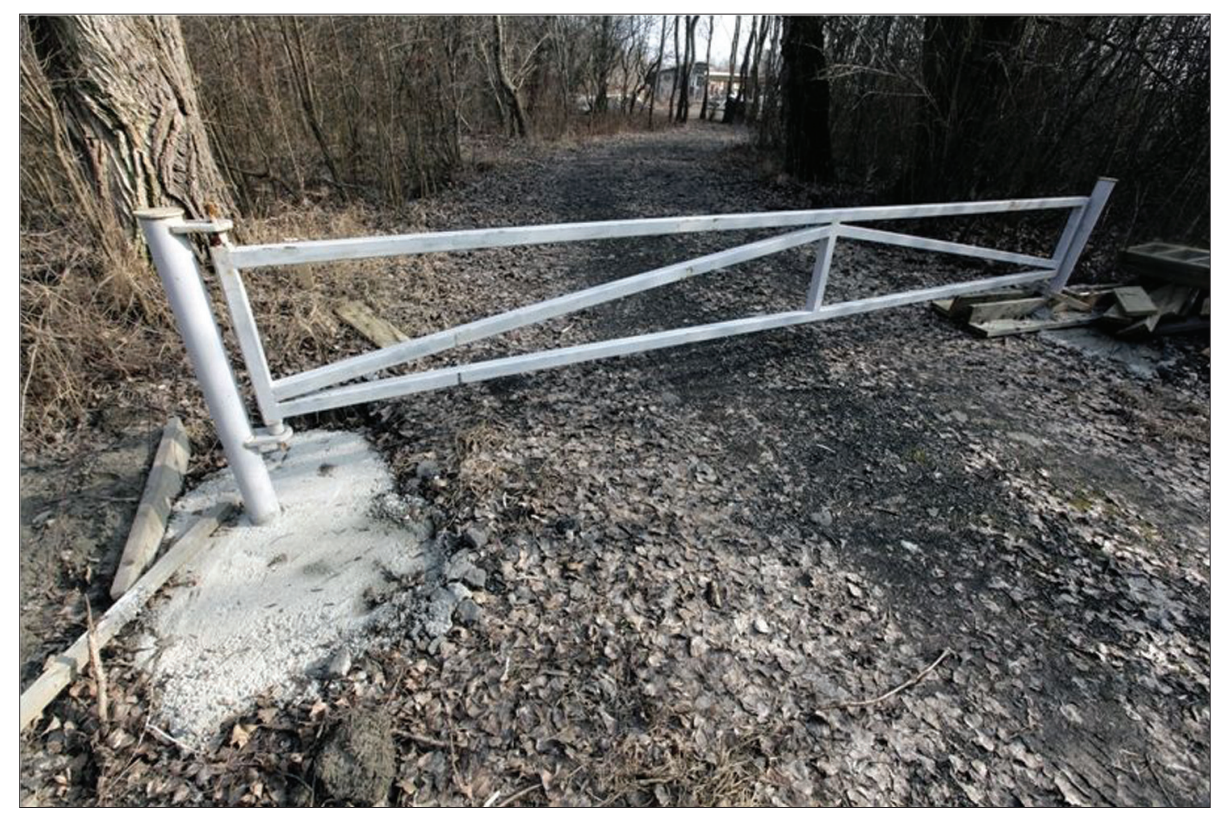

Photo 4. Privately built gate preventing access on the path. Source: www.pluska.sk 
river branch by a small group of people who occupied this valuable territory. Unregulated, linear development of private boathouses can prevent easy and free access to the Danube's banks which can be considered as a public asset.

Some of the owners of boathouses highlighted the fact, that newcomers are advised by their friends, owners of old boathouses, how to privatise their surroundings. Among the newcomers and owners of new boathouses influential people with high public positions can be found such as: members of parliament, ministers, and mayors.

Consequently, we can summarise that the illegal privatisation of public land has been initiated by a relatively small group of affluent people and their effort to obtain control over the Jarovce river branch can be understood as the uncontrolled creation of a semi-gated community on water.

\section{The role of public institutions}

From an institutional point of view the urbanisation of water surfaces in Bratislava shows not only weak coordination between different hierarchy levels of public administration (i.e. lack of real multilevel governance), but also a low rate of cooperation among public institutions of the same level. Despite the pressure from the public and the media, the mushrooming of boathouses near the Danube continued. However, the mentioned pressure and negative publicity set into motion two public institutions for action: the Slovak Water Management Enterprise and the Water Construction Enterprise. Until 2013, the illegal development in the Jarovce river branch had been tolerated by public authorities.

As a symbol of scandalous practices reflecting the gap between private and public interests practices of the Ministry of Environment in the period 2006-2009 can be mentioned, when publically owned flood land was rented to a private company for 99 years. In spite of the fact that the contract was later cancelled by the prosecutor, such agreement would have given enormous power to a private developer and control over the access to the Jarovce river branch. Future tenants would have needed the permission of the company for obtaining a place in Jarovce river branch. Only recently have authorities started to act in order to clear at least the infamous constructions built on the river bank.

\section{Conclusions}

In this paper we demonstrate the uneven struggle for access to water in post-socialist Bratislava. We focuse on locations which are essential parts of the waterfront transformation story. The ongoing waterfront transformation in Bratislava confirms the conflicting nature of highly exposed localities and reflects the contradictory 
interests of various stakeholders. The current use of waterfronts is characterised by asymmetric power relations among the main actors of urban development.

The unevenness in access to water is shown on two localities with sharply contrasting character of transformation. The first case, Karlova Ves cove, is an environmentally highly valuable area with a historical relation to water and water sports, which is guaranteed by the LUP of the city and also by the relatively large community of citizens. However, the course of transformation shows the weak position of water-enthusiasts and citizens who struggle for the access to the Danube and future use of this area. The driving force behind this process is the endeavour of a private investor to maximise the exchange value of the land under the existing legislative and spatial planning environment of a rapidly transforming post-socialist city.

The second case shows the robust transformation of an environmentally very valuable area, the Jarovce river branch, where the invasion of a small group of affluent newcomers and the illegal privatisation of public land can be observed. The 'wild urbanisation' of Jarovce river branch and the endeavour of newcomers to privatise public property is accompanied by the development of an illegal semi-gated community on the river bank.

Both case studies raise two important concerns related to asymmetric power relations in post-socialist urban space, namely the role of spatial planning and legislation in urban development and the attitude of public institutions in post-socialist urban development.

Firstly, the mechanism of spatial planning is still from the time of communism and it is a very exclusive matter. The planning process of the city or city districts as well as the interpretation of LUP is very technocratic, rigid and has hardly any connection with the wider public. The spatial planning process is the domain of a relatively small group of experts who are planning for the citizens, without them. This persisting system increases its inclination to strong individual interests. Secondly, the widening possibilities of private investors were shown to control the future development of an area through spatial planning documentation. The authors of planning documents are often private companies whose intention to protect public interest, consider wider relations as well as prefer functions with high use value are very limited. Lastly, our criticism also goes to the land based character of spatial planning process in general by which we follow PINCH, P. and MunT, I. (2002). Functions primarily dependent on water are not recognised at all and are misrepresented by land based codes. Planning, therefore, does not integrate river into the wider urban environment. This planning can result in the degradation of the importance of the river for the city.

The second group of problems we want to underline here is the behaviour of public institutions in the process of urban development. We came to similar conclusions as Feldman, M. (2000), who showed the fragile status of the municipality in relation to its fiscal, political and organisational status 
as well as the whole institutional fragmentation and absence of cooperation among public stakeholders. Additionally, we want to highlight a significant difference between the de facto and de jure position of post-socialist institutions in Bratislava. Whereas the position of public authorities is de jure relatively strong and they are equipped with robust regulatory tools, these tools are, however, de facto not used effectively, or misused through technocratic and non-participatory procedures. As the Jarovce river branch case showed there are significant limits in coordination and multilevel-governance among different public institutions.

In conclusion we want to make some possible normative suggestions. Besides the solutions to our above mentioned criticism, we believe that the concept of locally embedded leadership in the highly organised network of stakeholders (regardless their hierarchical position) is the key to improvement. This might be initiated not exclusively from the public sector; however, the role of entrepreneurial public institutions is essential in the fight against social, spatial and environmental injustices in urban development of post-socialist cities.

Acknowledgements: This paper was supported by the Grant Agency of the Charles University No. 852513 “Whose waterfront regeneration?" 


\section{REFERENCES}

Breen, A. and Rigby, D. 1994. Urban Waterfronts: Cities Reclaim Their Edge. New York, McGrawHill.

Brottomesso, R. 1993. Waterfronts: A new frontier for cities on water. Venice, International Centre for Cities on Water.

BUČEK, J. 2006. Post-socialist urban development, planning and participation - The case study of Bratislava City Centre. In Social changes and social sustainability in historical urban centres

- The case of Central Europe. Eds. Enyedi,G. and Kovícs, Z., Pécs, Centre for Regional Studies, Hungarian Academy of Sciences. Discussion Papers Special, 65-80.

Castells, M. 1996. The rise of the network society. Oxford, eBlackwell Publishers.

Соок, A. 2010. The Expatriate Real Estate Complex: Creative Destruction and the Production of Luxury in Post-Socialist Prague. International Journal of Urban and Regional Research 34. (3): 611-628.

Coincetto, E., 2007. The Role of the Development Industry in Shaping Urban Social Space: a Conceptual Model. Geographical Research 45. (4): 340-347.

Desfor, G., Laidley, J., Stevens, Q. and Schubert, D. eds. 2011. Transforming Urban Waterfronts, Fixity and Flow. New York, Routledge.

Doucet, B., Kempen, R. and VAn Weesep, J. 2010. Resident perceptions of flagship waterfront regeneration. the case of the Kop van Zuid in Rotterrdam. Tijdschrift voor Economische en Sociale Geografie 102. (2): 125-145.

Feldmann, M. 2000. Urban Waterfront Regeneration and Local Gouvernance in Tallinn. EuropeAsia Studies 52. (5): 829-850.

Gordon, D.L.A. 1996. Planning, design and managing change in urban waterfront redevelopment. Town Planning Review 67. (3): 261-290.

Gordon, D.L.A. 1997. Managing changing political environments in urban waterfront development. Urban Studies 34. (1): 63-83.

Harvey, D. 1989. The Condition of Postmodernity. Oxford, Blackwell.

Harvey, D. 2014. Seventeen Contradictions and the End of Capitalism. London, Profile books Ltd.

Hoyle, B.S., Pinder, D.A. and Husain, M.S. 1988. Revitalising the Waterfront: International Dimensions of Docklands Development. London, Belhaven Press.

Hoyle, B. 2000. Global and Local Change on the Port-City Waterfront. Geographical Review 90. (3): 395-417.

ILÍK, J. and OuŘEDNíčEK, O. 2007. Karlín a jeho promněny v souvislostech postsocialistické transformace Prahy. Geografie 112. (3): 292-314.

Imrie, R.; Lees, L. and Raco M. eds. 2009. Regenerating London: Governance, Sustainability and Community in a Global City. London, Routledge.

KIss, É. 2007. The evolution of industrial areas in Budapest after 1989. In The post-socialist city. Urban form a space transformations in central and eastern Europe after socialism. Ed. STANILOv, K. Dordrecht, Springer, 147-170.

Malone, P. ed. 1997. City, Capital and Water. London, Routledge.

Marcuse, P. and Van Kempen, R. eds. 2000. Globalizing Cities. A New Spatial Order? Oxford, Blackwell.

Marshall, R. ed. 2001. Waterfronts in Post-Industrial Cities. London, Spon Press.

Nedović-Budić, Z. 2001. Adjustment of Planning Practice to the New Eastern and Central European Context. Journal of the American Planning Association 67. (1): 38-50.

Pinder, D. A. and Hoyle, B.S. 1992. Urban waterfront management: historical patterns and prospects. In Ocean Management in Global Change. Ed. FABbRI, P. London and New York, Elsevier. 493-516. 
Pinch, P. and Munt, I. 2002. Blue Belts: An Agenda for 'Waterspace' Planning in the UK. Planning Practice and Research 17. (2): 159-174.

Scharenberg, A. and Bader, I. 2009. Berlin's waterfront site struggle. City 13. (2-3): 325-335.

Short, J.R., Benton, L.M., Luce, W.B. and Walton, J. 1993. Reconstructing the image of the industrial city. Annals of the Association of American Geographers 83. (2): 207-224.

Stanilov, K. ed. 2007. The post-socialist city: urban form and space transformations in Central and Eastern Europe after socialism. Dordrecht, Springer. 495 p.

SýKORA, L. 2001. Proměny prostorové struktury Prahy v kontextu postkomunistické transformace. In Regionální vývoj: specifika české transformace, evropská integrace a obecná teorie. Ed. Hampl, M. Praha, 127-166.

SÝкоRA, L. 2007. Office development and post-communist city formation. In The Post-Socialist City: Urban Form and Space Transformations in Central and Eastern Europe after Socialism. Ed. Stanilov, K. Dordrecht, Springer. 117-145.

SýKORA, L. 2008. Revolutionary change, evolutionary adaptation and new path dependencies: socialism, capitalism and transformations in urban spatial organizations. In City and Region. Papers in Honour of Jiři Musil. Eds. Strubelt, W. and Gorzelak, G., Leverkusen-Opladen, Budrich UniPress. 283-295.

Sýkora, L. and Bouzarovski, S. 2012. Multiple Transformations: Conceptualising the Postcommunist Urban Transition. Urban Studies 49. (1): 43-60.

Swyngedouw, E. 2004. Social power and the urbanization of water. Flows of power. Oxford, Oxford University Press.

Temelová, J. 2009. Urban revitalization in central and inner parts of (post-socialist) cities: conditions and consequences. In Regenerating Urban Core. Ed. IlmavirTa, T., Helsinki, Helsinki University of Technology, Centre for Urban and Regional Studies, 12-25. 